\title{
The experience of aggression by female teachers in the workplace
}

\author{
D.S. van der Merwe ${ }^{a, *}$, C.P.H. Myburgh ${ }^{b}$, M. Poggenpoel ${ }^{c}$ \\ ${ }^{a}$ University of Johannesburg, South Africa \\ ${ }^{\mathrm{b}}$ Department of Educational Psychology, University of Johannesburg, PO Box 524, Auckland Park, 2006, South Africa \\ c Department of Nursing Science, University of Johannesburg, South Africa
}

\section{A R T I C L E I N F O}

Article history:

Received 11 March 2015

Accepted 29 May 2015

Available online 19 August 2015

\section{Keywords:}

Aggression

Experience

Female teachers

Workplace

Qualitative

Phenomenological in-depth

interviews

\begin{abstract}
A B S T R A C T
South Africa is a country with exceptionally high levels of frustration and trauma. Research shows that a third of all people in South Africa are exposed to some kind of violence. This causes insecurity and fear, which creates high levels of stress. High stress levels fuels aggression in the workplace. It was observed that female teachers often experience aggression in the workplace. This has a negative effect on their overall sense of well-being as well as their mental health. A purposive sample was selected through two private schools in Gauteng, South Africa, and consisted of eight female teachers. Data was collected by means of in-depth phenomenological interviews, field notes, naive sketches and observation. One central question was posed to the purposefully selected participants: What is your experience of aggression in your workplace? Thematic coding was used to analyse the data. Three themes were identified: different perceptions influenced female teachers' experience of aggression; the pressure in the school system formed an integral part of the experience of aggression and the experienced effect of aggression on the female teachers.
\end{abstract}

\section{O P S O M M I N G}

Suid-Afrika is ' $n$ land met hoë vlakke van frustrasie en trauma. Navorsing toon aan dat een derde van alle persone in Suid-Afrika al aan die een of ander vorm van geweld blootgestel was. Die gevolge hiervan is onsekerheid en vrees wat lei tot hoë vlakke van stres. Hoë vlakke van stres bevorder dikwels aggressie in die werkplek. Dit is waargeneem dat vroulike onderwysers aggressie in die werkplek beleef. Dit het ' $n$ negatiewe uitwerking op hulle algemene welsyn asook hulle geestesgesondheid. ' $n$ Doelgerigte steekproef is getrek uit twee privaatskole in Gauteng, Suid-Afrika en het bestaan uit agt vroulike onderwysers. Data is met behulp van indiepte fenomenologiese onderhoude, veldnotas, naïewe sketse en waarneming ingesamel. Een sentrale vraag is aan die doelgerig-gekose deelnemers gestel: Wat is jou ervaring van aggressie in jou werkplek?

\footnotetext{
* Corresponding author.

E-mail address: chrism@uj.ac.za (D.S. van der Merwe).

Peer review under responsibility of Johannesburg University.

http://dx.doi.org/10.1016/j.hsag.2015.05.004

1025-9848/Copyright @ 2015, Production and hosting by Elsevier B.V. on behalf of Johannesburg University. This is an open access article under the CC BY-NC-ND license (http://creativecommons.org/licenses/by-nc-nd/4.0/).
} 
Tematiese kodering is gebruik om die data te analiseer. Drie temas is geïdentifiseer: verskillende persepsies het vroulike onderwysers se belewing van aggressie beïnvloed, die druk in die skoolstelsel het ' $n$ integrale deel van die belewing van aggressie gevorm en die beleefde uitwerking van aggressie op die vroulike onderwysers.

Copyright $\odot$ 2015, Production and hosting by Elsevier B.V. on behalf of Johannesburg University. This is an open access article under the CC BY-NC-ND license (http:// creativecommons.org/licenses/by-nc-nd/4.0/).

\section{Introduction and background}

Aggression is embedded in the culture of society. It is internalised in childhood and adolescence and manifests in a variety of situations throughout life (Tehrani, 2001:7; Venter, Poggenpoel, \& Myburgh, 2005:312). Aggression is not a new phenomenon in society. Aggression in the workplace is not a new challenge (Vega \& Comer, 2005: 101). Aggression possibly started when one person started working for another person (Van Waltsleven, 2007:6). Behaviour in the workplace that was tolerated in the past is no longer acceptable (Peyton, 2003:3). The actuality of this challenge is stressed by the existence of websites, like the Workplace Bullying Institute (Jefferson, 2008:50). According to Björkqvist (2001:439), the phenomenon of aggression in the workplace is not only related to a specific culture, but is a universal problem.

Like every country, South Africa has its own challenges. Baron and Byrne (2004:437) state that aggressiveness results from increased levels of frustration arising from environmental challenges such as poverty and unemployment. South Africa is a country with exceptionally high levels of frustration and trauma (Einarsen, Hoel, Zapf, \& Cooper, 2003:212). Aggression in the form of house robberies, rapes, xenophobia, hijackings, road rage and murder is everyday news. Research shows that a high percentage of all people are exposed to some form of violence (Carstens, 2009:23). Aggression, frustration and stress levels run high.

Schooling in South Africa takes place in public schools, former model C schools, private schools and alternative learning schools (ExpatArrivals, 2014: 1-3). The public schooling system is entirely dependent on the government for funding and supplies. Overall with a serious lack of financing and monitoring from the government, many children receive low standards of education, a lack of qualified teachers and sometimes an outright absence of equipment in the classroom. The former model C schools, as government schools partially administrated and funded by parents and a governing body. Private schools in South Africa have an excellent reputation and offer internationally recognised exams. Children from these schools have excellent acceptance rates into tertiary education worldwide. Alternative and art schools, are becoming increasingly popular with expat parents with younger children.

The research reported in this article refers to a group of private schools within a corporation. Previous research on female teacher's experience of their own aggression (Evangeledis, 2007:96) took place in a secondary school that was part of this corporation of private schools that was managed by a central head office. Participants in the research (Evangeledis, 2007:95-129) identified several challenges in the private school setting including that the staff at head office were viewed as business oriented, insensitive to female teachers' personal needs and did not take cognisance as how schools in general operate. Female educators also experienced that there were some teachers who were incompetent as well as a lack of solidarity under teachers. The participants also voiced that there was a lack of communication between stakeholders, the school and head office. Female teachers experienced that balancing their chosen careers with that of looking after their families challenged them as individuals. They found it difficult to maintain a healthy equilibrium between the two demands. The female teachers also experienced time restraints and an unceasing workload that impacted negatively on their mental health.

It is not always easy to identify aggression. According to Peyton (2003:5), if people do communicate that they experience aggression, they usually only speak to family or friends about it. Normally they do not tell anybody and just leave their jobs. The results of aggression in the workplace are negative: the staffs is unmotivated with a loss of spontaneity and enthusiasm, high incidence of sick leave, high staff exchange and the threat of a potential court case (Peyton, 2003:5). Often the morale of the staff is low, and all the negative feelings create a toxic atmosphere.

Aggression in the workplace gives the employer a bad reputation. A bad reputation makes it very difficult for an employer to recruit good employees. The best solution is to handle and dissolve the aggression when it takes place and not to postpone it (Rayner, Hoel, \& Cooper, 2002: 36).

\section{Problem statement and objective}

Venter, Poggenpoel and Myburgh (2005:312) as well as Feldman (2001:325) identify frustration as a psycho-social factor that encourages aggressive behaviour. Baron and Byrne (2004:437) state that aggressiveness often results due to the high frustration levels present in environmental problematic situations such as poverty and unemployment. South Africa is a country with unusually high levels of frustration and trauma at all levels (Einarsen et al., 2003:23). The insecurity and uncertainty about the present and the future create stress. High stress levels can promote aggression in the workplace such as the school environment (Einarsen et al., 2003:15).

Female teachers' daily workload is difficult to handle and they struggle to achieve the standard of work that is expected of them, as well as the goals that they set for themselves. Female teachers experience the target group 
that they teach as a challenge. Their incapability to reach the required goals creates frustration in themselves (Feldman, 2001:305). The fact that they have a caregiving job, which in itself has been identified as an empathetic job where they could become victims of aggression, as well as being caregivers to their family, makes them vulnerable. These female educators' work responsibilities must be handled alongside the responsibilities of their family. Problems at work as well as problems at home can be astronomical, depending on their situation. Interpersonal relationships among colleagues, seniors and family pose an ongoing challenge (Van Waltsleven, 2007:2). Frustration and stress are constant companions of the daily life of female teachers. However, very little published research exists on the experiences of female teachers in the workplace. Thus, against this background, the following research question was formulated:

"What is the female teacher's experience of aggression in the workplace?"

In view of the above, the objective of this empirical study was the exploration and description of female teachers' experiences of aggression in the workplace that is the private school environment.

\section{Research design and method}

The research design selected for this study was exploratory, descriptive, contextual and qualitative in nature. A phenomenological approach (Creswell, 2013: 60-61) was used to obtain the data. Female teachers, who met the criteria, participated by means of three options. Firstly, by means of an in-depth phenomenological interview and secondly they could participate in an interview as well as write a naïve sketch to supplement the interview. Thirdly, they could also participate by writing a naïve sketch only. Observations were made throughout the research and field notes made.

The interviews were conducted until data saturation was obtained (Creswell, 2008:257-258). All the interviews were audio-taped, transcribed and analysed by using Tesch's thematic coding (Creswell, 2008:154-155). All the transcripts of the interviews (7), naïve sketches (3) and field notes were read and reread to obtain a sense of the participants' experience of aggression in the workplace. During this, units of meaning relevant to aggression in the workplace were identified (Streubert \& Carpenter, 2007:45-46). These units of meaning were labelled and eventually grouped together, and translated into themes. The themes were supported by direct quotations from the participants gathered during the interviews. An independent coder's services were used during the data analysis stage. A consensus discussion between the researchers and the independent coder was conducted. A literature control was done to verify the results (Creswell, 2008:88; Myburgh \& Strauss, 2013:98; Streubert \& Carpenter, 2007:26). To confirm the research, an audit trail was left (Streubert \& Carpenter, 2007:49).

\subsection{Measures to ensure trustworthiness}

In order to ensure the trustworthiness of this research, Guba's model in Lincoln and Guba (Krefting, 1991:214) was applied. Four constructs reflect the assumptions of a qualitative paradigm: credibility, transferability, dependability and confirmability. Techniques to achieve credibility included prolonged engagement in the field, varied field experiences and triangulation (De Vos, Strydom, Fouché, \& Delport, 2011: 277 \& 285; Van der Merwe, 2013:57). In this study the researcher spend six months in two private schools. Data were collected through in depth phenomenological interviews, naïve sketches and observation and field notes. Peer review took place throughout the research process by two supervisors. Transferability was achieved by a dense description of research methods, a description of samples and purposeful sampling (De Vos et al., 2011:346; Van der Merwe, 2013:57). In this research the demographics of the participants were described. A rich description of the results was provided supported by direct quotations from participants as well as a discussion of supporting literature. Techniques to achieve dependability included triangulation of data research methods, dense description of research methods and coderecode procedures (Streubert \& Carpenter, 2007:97-98; Van der Merwe, 2013:61). A dense description of the research methodology was given in this study. Finally, confirmability was achieved by applying reflexivity, leaving an audit trail and triangulation (Streubert \& Carpenter, 2007:98; Van der Merwe, 2013:61-62). A chain of evidence, that is research proposal, transcribed interviews, naïve sketches, field notes, data analysis and research report, was provided for the whole research process of this study.

\subsection{Ethical measures}

Since this research is sensitive in nature, the ethics were of particular importance. Ethical measures were adhered to during the entire research process. In order to ensure the ethical measures, Creswell's (2008:12-13) framework was implemented: respecting the rights of the participants, reporting research fully and honestly and honouring research sites and ethical context. Informed consent was obtained from the participants and the school principals. The Research Ethics Committee of the Faculty of Education of the university gave ethical approval for this research-Ethical Clearance Number 2010-030. Confidentiality and anonymity were ensured at all times. The participants had the right to withdraw at any time during the study if they wanted to (Creswell, 2008:11-13; Myburgh \& Strauss, 2013:71; 38-39; Van der Merwe, 2013: 38-40).

\section{Results}

To obtain the results for this empirical investigation, participants were purposefully selected from two private schools in Gauteng. Eight female teachers, aged 34-63 years, participated. The female teachers had 8-34 years of experience in teaching with a minimum of 3 years of teaching experience in the private schools. Seven interviews were conducted and 
three naïve sketches were collected as data. The inclusion criteria for participating were that the teacher should not occupy a managerial position while experiencing the aggression. Secondly, teachers should have had a minimum of three years' teaching experience, preferably at the same school and lastly should have had experience of aggression in the workplace.

The female teachers experienced strong negative emotional responses on their experiences of aggression in the private school environment such as feelings of hurt, hopelessness, powerlessness, distrust, humiliation, guilt, stress, anxiousness, fear, inferiority and depression; in addition, many tears were shed.

The result of this research is described in three themes that were identified from the data. These themes were that different perceptions influenced female teachers' experience of aggression; the pressure in the school system formed an integral part of the experience of perceived aggression and the effect of experiences of aggression on female teachers. The three themes mentioned above are discussed below with relevant quotations from the interviews, naïve sketches, field notes and accompanying literature discussions. See Table 1 for an overview of the results.

\section{Theme 1: different perceptions influence the experience of aggression}

Some female teachers experienced developing the perception that they are victims of aggression in the workplace. Female teachers who perceived that they are good natured experienced that they were abused due to this characteristic. The teachers who were accommodating, who find it hard to stand up for themselves and those who are peace-loving, all experienced aggression. Aggression was experienced when personalities of female teachers clashed.

The perception that females are emotional, seemingly promotes aggression. These perceptions are illustrated by quotes from the interviews (Van der Merwe, 2013:65):

"I feel that everybody abuses my good nature" (Participant \# 4).
"In my work environment it has been very difficult to stand up for myself" (Participant \# 4).

"Women are also inclined to become more emotional" (Participant \# 7).

Scott-Lennon and Considine (2008:36) mention that women who find it difficult to stand up for themselves can become victims of aggression. Participants experienced aggression when they have to try keeping the peace, while the aggressor is constantly cross. Anger is experienced as aggression. Tehrani (2004:191) states that threatening and intimidating behaviour is identified as aggression. Rayner et al. (2002:95) explain that some individuals use their strong personalities to threaten others. Literature confirms that when personalities clash, aggression could develop (Jefferson, 2008:50; Rayner et al., 2002:96).

Rayner et al. (2002:107) state that female teachers experiencing aggression tend to be introverts, conscientious and submissive. Research indicates behaviour types $\mathrm{A}$ and $\mathrm{B}$. Behaviour type B is described as relaxed, gentle, unhurried and content. Behaviour type A is described as competitive, aggressive, hasty, impatient, restless, with explosive speech, showing feelings that the individual is under time and workload pressure (Randall, 2002:46). Individuals who try to control a group situation demonstrate higher levels of aggression than others. This links to the concept that individuals should monitor themselves. Behaviour type A finds it difficult to adjust their behaviour to changing circumstances (Randall, 2002:46). On the other hand, people who are sensitive and good at self-monitoring, adjust their words and behaviour to make a good impression on others (Randall, 2002:46).

Women are generally viewed as emotional (Johnson, 2009:356). An individual's thoughts and feelings dictate their behaviour. Unpleasant thoughts and negative moods are associated with irritability and anger. "In brief, people who feel uncomfortable are more likely to show aggressive behaviour than those who do not" (Randall, 2002:47). The individual's perception of that specific moment provides the way in which the world is experienced.

\section{Table 1 - Overview of the results: themes and categories of female teachers' experiences of aggression in the workplace.}

Themes

Theme 1: Different perceptions influenced the female teachers' experience of aggression

Theme 2: Pressure in the school system was experienced as an integral part of the experience of aggression

Theme 3: Female teachers experienced the effect of aggression on themselves

\section{Categories}

Experience of perception of own personality

The pressure of workload

The experience of interpersonal pressure

Experience of aggression in connection with work incidents

Experience of professional jealousy

Experience of lack of recognition

The experience of aggression by means of passive non-verbal aggressive behaviour

Physical symptoms due to aggression

Psychological symptoms due to aggression

Experienced an interpersonal effect such as withdrawal

Experienced critical personal assessment, decrease in self-worth and inferiority 
The specific personality and emotion of the female teacher could make her more receptive for potentially experienced aggression that could result from pressure in the school system (Van der Merwe, 2013:67).

\section{Theme 2: pressure in the school system was experienced as an integral part of the experiences of aggression}

Workload, unreachable expectations, privileged staff, as well as specific times in the year, were responsible for female teachers experiencing aggression. Interpersonal pressure, in the form of perceived unfairness, discrimination and victimisation were experienced as aggression. In workrelated incidents, the perceived aggression was wide spread and entailed withholding, humiliation and continuous negative criticism. Success, especially public success, good examination results, improvement of qualifications and promotion, also provoked aggression due to professional jealousy. A lack of recognition needs to be highlighted, as it is experienced as a big source of aggression. Aggression was also experienced by means of passive, non-verbal aggressive behaviour.

\section{- Experience of pressure of workload}

Workload was identified as one the biggest factors in female teachers' experience of aggression in the workplace. Workload and work pressure were interweaved and had to do with time: the amount of time available and the time of the year. Sometimes the teacher was struggling to manage her own workload when more work was passed down from her senior, who also could manage her own workload. They did not complain, as they did not want to be seen as failures. The high expectations at all levels in the private school, especially with regard to lesson preparation, instigated perceived aggression (Van der Merwe, 2013:68):

"Especially in a private school where you do not use government textbooks. You have to prepare each lesson yourself. You have to type your own notes in such a way that the children are able to use them for learning for the examination. It is a lot of work, so you are always tired" (Participant \# 5).

"We work under terrible pressure at this school. This is a highpressured school; many things happen here” (Participant \# 2).

"It depends on the time of the year. Who is busy with reports and there's stress ..." (Participant \# 2).

Vega and Comer (2005:104) state that an unmanageable workload causes aggression in the workplace. Botha (2008:209) identifies it as the number one challenge that employees experience. High expectations and unreachable deadlines provoke aggression and create a pressure cooker organisation (Botha, 2008:207-209; Rayner et al., 2002:112; Vega \& Comer, 2005:104). Rayner et al. (2002:112-114) state that workload and work pressure are higher at certain times of the year and the staff then experience more stress and exhaustion. They say that many researchers have already tried to explain aggressive behaviour in the context of the stress phenomenon. The perception with regard to workload and work pressure affects interpersonal relationships.

- The experience of interpersonal pressure

Aggression experienced was perceived as unfairness, discrimination, victimisation, inconsistency, favouritism, marital status, age and class differences.

"When is this victimisation gonna stop, because I've had enough now, because you keep on contradicting yourself" (Participant \# 3).

"You know, so she, she, you always felt, you're not in her class, and, uh, uh, uh, you're only a worker" (Participant \# 6).

“... people who do less than you but earn more money than you ...” (Participant \# 3).

Unfair treatment, victimisation, inconsistency and wrong information are all examples of aggression (Boddy, 2011:367; Botha, 2008:207 \& 209; Randall, 2002:42; Scott-Lennon \& Considine, 2008:14; Vega \& Comer, 2005:104). To convey wrong information can undermine a person's reputation, and to undermine someone's reputation is aggression in the workplace (Krahe, 2001:123). Discrimination is a well-known form of aggression (Botha, 2008:209) and happens at several different levels such as experienced in this research: marital status, with or without children, class differences and age (Rayner et al., 2002:29). Research (Tehrani, 2004:189) shows that aggression in the workplace is strongly influenced by status. An authoritative management style is associated with aggression (Rayner et al., 2002:114; Tehrani, 2004:195). Participants in this research experienced status and class differences to result in aggression (Rayner et al., 2002:95).

- Experience of aggression in connection with work incidents

The female teacher experienced aggression related to work incidents such as withholding, humiliation and a lack of recognition. Withholding took place at the level of information, study material, opportunity, absenteeism and shortage of preparation time. Humiliation were experienced when the female educator was disgraced by other teachers saying her work were not on standard. The participants experienced psychological discomfort: they were silenced, received written warnings, anger were voiced towards them, were put in a bad light, were transferred to a class below their capacity and received undermining, constant negative critique, the aggressor is always on the third party's side, were reprimanded and degraded, the aggressors made the situation more difficult and they were yelled at (Van der Merwe, 2013:73).

\footnotetext{
"When someone yells at me ..." (Participant \# 2).

"You can never tell her about your problem, because she exaggerates it ..." (Participant \# 8).
} 
"And she was the type of person, who questioned everything you did and always tried to see something in a negative way, and tried to get you to accept her point of view " (Participant \# 7).

To be yelled at is viewed as aggression (Kruger, 2012:4; Rayner et al., 2002:108; Scott-Lennon \& Considine, 2008:14). Being threatened by someone, as well as receiving written warnings, as experienced in this study, are described as aggression in the workplace (Scott-Lennon \& Considine, 2008:14). Rayner et al. (2002:52) mention that initially the female teachers try to discuss the problem in an effort to solve it. Participants experienced that they are silenced. Scott-Lennon and Considine (2008:14) identify silencing as aggression.

According to Botha (2008:207), to allocate work to a person below her capacity, like degrading someone with an honours degree to grade four, is typical of aggression in the workplace. Lessons that took a very long time and hard work to prepare are take and handed over to someone else. Female educators who have invested a great deal in their work and have given much to an organisation, finds it hard to see the world as meaningful in the way they originally conceptualised it (Rayner et al., 2002:49). Aggression takes place when small problems are exaggerated (Rayner et al., 2002:102). Withholding is a form of sabotage and is typical of aggression (Kruger, 2012; Scott-Lennon \& Considine, 2008:17; Vega \& Comer, 2005:104; Wiedmer, 2011:37). To expect a high standard of work, but not to provide enough time to achieve it, is to set an impossible goal (Botha, 2008:207). Many researchers identify constant criticism, downgrading and questioning as aggression in the workplace (Botha, 2008:207; Rayner et al., 2002:102; Vega \& Comer, 2005:104; Wiedmer, 2011:37). Aggression in the workplace has one main aim: to accuse the victim of poor work performance (Botha, 2008:207). Aggression intensifies if professional jealousy surfaces and will be further discussed in the next section.

- The experience of professional jealousy

Professional jealousy was experienced with regard to potential as well as present success. Public success, good examination results, promotion, improvement of qualifications and recognition provoked jealousy. Aggression experienced in relation to jealousy were ganging up, undermining, hostility, being put in a bad light, being accused, gossip, downgraded and questioned (Van der Merwe, 2013:78-79).

"A big factor, for me personally, that encourages aggression, is professional jealousy amongst female colleagues on the staff ..." (Participant \# 2).

"A large factor for me personally that elicits aggression, is the professional jealousy between female colleagues on the staff" (Participant \# 2).

“... she thinks it's the most retarded thing. It is the simplest course ever and in the very next year she enrols herself for the same course" (Participant \# 7).

Any form of hostility (Krahe, 2001:124), as well as ganging (De Wet, 2011:67; Tehrani, 2004:191), is seen as aggression.
When it comes to undermining, the aggressor sometimes has the motive to block the victim's promotion (Krahe, 2001:123). The participants experienced aggression in the form of hostility when their successes were acknowledged (De Wet, 2011:57; Krahe, 2001:123). Often it is the best female teachers, rather than the weakest, who become victims of aggression (Wiedmer, 2011:36). The improvement of qualifications often results in aggression (Botha, 2008:207). This research identified the experience of a lack of recognition as prominent.

\section{- The experience of lack of recognition}

The female teacher experienced aggression due to a lack of recognition. They experienced that they were left out or forgotten, and that the aggressor was the person who was wrongly recognised for the work that they had done (Van der Merwe, 2013:83).

"I am often overlooked or forgotten to be publicly acknowledged for the work I deliver" (Participant \# 4).

"... as long as she can do something for the boss, as long as she's able to win the approval of the boss, she will be happy, but if she can't do it, she wouldn't be happy ..." (Participant \# 3).

"So the girl and me gave the learners extra classes during the holiday to prepare them- and, then she is thanked for it." (Participant \# 8).

Health Insight (2006:1) views the lack of recognition as a classic job problem. The participants regard not being credited for their hard work, as well as other people taking credit for their work, as aggression in the workplace (Botha, 2008:209; Jefferson, 2008:51; McGarth et al., 2003:555-565; Scott-Considine, 2008:17; Wiedmer, 2011:37). According to Rayner et al. (2002:102), if employees are not acknowledged, they experience that they are not appreciated.

- The experience of aggression by means of passive, nonverbal aggressive behaviour

The female teacher experienced aggression by means of passive, non-verbal aggression such as negative facial expressions, iciness, quibbling, exclusion, sarcasm, back stabbing, gossiping, continuous criticism, irritation, ganging, undermining, negative remarks and ignoring. Often it manifested in small but continuous incidents (Van der Merwe, 2013:85).

"You know it was very bad for me, I did not enjoy teaching because the two clicked and always 'chi chied' and then I felt like a fifth wheel on the wagon" (Participant \# 8).

"... the gossiping behind your back. The, uhm, the iciness ..." (Participant \# 7).

"... she ignored the fact that I was running (the Comrades) and I had to do my exam. I passed my exam at UJ with honours" (Participant \# 1). 
Tehrani (2004:19) confirms that aggression can manifested in different forms as experienced by the female teachers, and that it can be exercised by means of subtle aggression (De Wet, 2011:67). Something ordinary, like facial expression, can be intimidating. Constant, small remarks or criticism, or quibbling over something unimportant, are typical manifestations of aggression (Botha, 2008:207; Scott-Lennon \& Considine, 2008:15; Tehrani, 2004:187 \& 191). Exclusion and ganging are aggressive behaviour and have negative effects that can result in the undermining of social relationships (Krahe, 2001:123; Scott-Lennon \& Considine, 2008:14; Tehrani, 2004:191). Sarcasm, to be discussed behind their backs and gossiping is regarded as aggression (Jefferson, 2008:51; Krahe, 2001:123; Kruger, 2012:4; Randall, 2002:12; Scott-Lennon \& Considine, 2008:14-16; Tehrani, 2004:191). Aggressors ignore their victims in many different ways (Kruger, 2012:4; Randall, 2002:12; Rayner et al., 2002:9; Tehrani, 2004:191; Wiedmer, 2011:37). One or more persons' ongoing negative communication directed at one individual is typical of aggression (Krahe, 2001:123) and has an effect on the female teacher - not only psychologically, but also at a physical level (Van der Merwe, 2013:88).

\section{Theme 3: experiencing the effect of aggression on the female teacher}

Concerning the effect of experiencing aggression on the female teacher, four categories were identified from the data. These are discussed in the section that follows.

- Physical symptoms due to aggression experienced by the female teacher

The female teachers experienced an itchy skin, headaches and trembles due to the effects of anxiousness and stress caused by aggression in the workplace. Some of the participants used medication for the symptoms.

“... started taking a pill before the opening ceremony, because I started trembling ...” (Participant \# 8).

“... I feel anxious” (Participant \# 1).

"I started skin-scratching, uhm ... sometimes I'm suffering with headaches. I've not been prone to getting headaches at all" (Participant \# 1).

According to Randall (2002:147) and Rayner et al. (2002:48), anxiousness, stress and headaches are symptoms experienced by victims of aggression. Dry mouth, trembling and other posttraumatic stress symptoms are viewed as results of aggression in the workplace (Krahe, 2001:124; Rayner et al., 2002:47).

- Psychological symptoms due to aggression experienced by the female teacher

The female teachers experienced many psychological symptoms due to aggression in the workplace such as general discomfort, worrying, frustration, self-consciousness, abuse, disappointment, fear, stress, to feel hurt, cry, humiliation, betrayal, distrust, heartache, anxiousness, guilt, depression, and life simply being made difficult by the aggressor (Van der Merwe, 2013:90).

"The fact that she betrayed me was very traumatic for me" (Participant \# 6).

“... and often leads to depression” (Participant \# 4).

“... unresolved anger, and, uh, unrealistic guilt within me" (Participant \# 1).

The female teachers tried to not think about the experience of aggression, but it kept worrying them (Tehrani, 2004:49). They experienced being hunted by the aggressor but dropped by their colleagues and friends at this point where their support is so urgently needed (Rayner et al., 2002: 49). According to Krahe (2001:123), the victims can experience conscious efforts by the aggressor to make life difficult. The stress and fear experienced due to the perceived aggression are typical under these circumstances (Barling, Kelloway, \& Frone, 2005:201; Krahe, 2001:123; Randall, 2002:19; Tehrani, 2004:194). Unrealistic feelings of guilt haunt the victims, the same as experienced by victims of rape, as bullying, like rape, is a personal attack (Rayner et al., 2002:47; Tehrani, 2004:187 \& 194-195). The aggressor makes a victim's life miserable and crying forms an integral part of being a victim (Krahe, 2001:123). The anger that is experienced due to the aggression moves to the inner world of the individual. As she accommodates and tries to be the peacekeeper, her struggle becomes an internal one. This often leads to depression (Barling et al., 2005:203; Frisby-Lowe, 2007:33; Krahe, 2001:124; Randall, 2002:18-20; Rayner et al., 2002:44; Tehrani, 2004:187). This widespread psychological discomfort had an effect on social relationships, for instance the victim's withdrawal.

- Experiencing the interpersonal effect like withdrawal

Participants withdrew and isolated themselves as a defence mechanism:

"I try normally to isolate me, maybe as to protect my inner feelings" (Participant \# 1).

“Therefore I am withdrawn” (Participant \# 1).

“... they ganged together” (Participant \# 8).

Initially the female teacher practices complex behavioural patterns, but eventually withdraws (Randall, 2002:14; Rayner et al., 2002:51 \& 53; Tehrani, 2004:194). Aggressors gang up and by doing that, force the victims to withdraw and isolate themselves (Scott-Lennon \& Considine, 2008:16). Isolation is one of an aggressor's goals (Botha, 2008:209). The victim tries to address the aggression initially, often without success, and eventually withdraws, resigns and leaves the school (Rayner et al., 2002:52; Wiedmer, 2011:37).

The fact that aggression affects social relationships is a reality (Krahe, 2001:123). Aggression results in isolation, loneliness, feelings of uncertainty, lowering of self-worth, 
inferiority and personality adjustments (Van der Merwe, 2013:94).

- The experience of critical personal assessment that led to a decrease in self-worth and the development of a perception of inferiority

When the female teacher experienced aggression, she felt that she lacked something and started doubting herself. The experience decreased her self-worth and inferiority developed. This process were accompanied by a series of strong negative emotions as well as pain, and resulted in depression. A low self-esteem very often created an opportunity that made her vulnerable for more aggression. A vicious circle was created. She was non-confrontational in nature and thought that she was the one who made the mistake. She felt unsure about herself and started making personality adjustments. Some female teachers decided to work ever harder, enrolled in further studies, tried to develop a thick skin or started complimenting the aggressor, even in an unrealistic way. Because their self-worth were so low and they struggled with stress, anxiousness, fear and depressive feelings, many of them experienced paralysis and were not capable of making decisions. They gradually started to realise that they basically had three choices: they had to put up with the aggression, confront the aggressor or leave the school. Some of the female teachers succeeded after being motivated for a period to generate the courage and take action. Others stay in limbo (Van der Merwe, 2013:94-95).

"... it unsettled me, you know, because I doubted myself" (Participant \# 6).

“... need to cope with low self-esteem ...” (Participant \# 4).

"I have been able to live with it, and continue to try and be Mrs Nice Girl, the usual me. However, this has changed ..." (Participant \# 4).

Aggression creates uncertainty and often precedes low self-esteem (Randall, 2002:147; Rayner et al., 2002:29-105). To make someone feel inferior is to undermine the self-concept, and it could increase the chances for further aggression as experienced in this research (Rayner et al., 2002:29; Scott-Lennon \& Considine, 2008:105). The motive of aggression is to harm (Krahe, 2001:123), with the ultimate goal that victim the will perform poorly (De Wet, 2011:67). There is a loss of self-respect (Rayner et al., 2002:51) and personality adjustments are made (Tehrani, 2004:194).

\section{Conclusion}

Although there are few studies available on the topic of the female teachers' experiences of aggression in the workplace in South Africa of which the researcher is aware, this phenomenon is an every-day reality. Three themes were identified. The themes were: different perceptions influenced female teachers' experience of aggression, the pressure in the school system formed an integral part of the experience aggression and the experienced effect of aggression on female teachers (Van der Merwe, 2013: 105-120).

The topic researched is controversial and Wiedmer (2011:39) describes it effectively as a theme engulfed in "a code of silence". Awareness about this phenomenon needs to be promoted and it needs to be given a name, be acknowledged, identified and addressed, as it has the capacity to poison a complete workplace (Vega \& Comer, 2005:101).

\section{R E F E R E N C E S}

Barling, J., Kelloway, E. K., \& Frone, M. R. (2005). Handbook of work stress. London: Sage Publications.

Baron, A. R., \& Byrne, D. (2004). Social psychology. Boston: Pearson Education Inc.

Björkqvist, K. (2001). Social defeat as a stressor in humans. Electronic version Physiology \& Behavior, 73, 435-442. Åbo Akademi University, Faasa, Finland.

Boddy, C. R. (2011). Corporate psychopaths, bullying and unfair supervision in the workplace. Journal of Business Ethics, 100, 367-379.

Botha, W. (2008). Developing an understanding of bullying targets' experience of and coping with abusive workplace situations. Unpublished doctoral thesis. Johannesburg: University of Johannesburg.

Carstens, S. (May 2009). Mans en depressie (pp. 22-24). Taalgenoot.

Creswell, J. W. (2008). Educational research: Planning, conducting, and evaluating quantitative and qualitative research. New Jersey, USA: University of Nebraska-Lincoln.

Creswell, J. W. (2013). Qualitative inquiry and research design, choosing among five approaches. London: Sage.

De Vos, A. S., Strydom, H., Fouché, C. B., \& Delport, C. S. L. (2011). Research at grass roots for the social science and human service professions. Pretoria: Van Schaik Publishers.

De Wet, N. C. (December 2011). The professional lives of teacher victims of workplace bullying: a narrative analysis. Perspectives in Education, 29(4), 66-77.

Einarsen, S., Hoel, H., Zapf, D., \& Cooper, C. L. (2003). Bullying and emotional abuse in the workplace. London: Taylor \& Francis.

Evangeledis, B. (2007). Facilitation of healthy self-management of female educators' experience of their aggression within a secondary school context. D. Ed Psychology of Education. Johannesburg: University of Johannesburg.

ExpatArrivals. (2014). Education and schools in South Africa. http:// expatarrivals.com/south-africa/education-and-schools-insouth-africa Accessed 16.09.14.

Feldman, R. S. (2001). Social psychology. New Jersey: Prentice Hall. Frisby-Lowe, A. (2007). My journey to the light. Victory over depression. Vanderbijlpark: Corals.

Jefferson, A. L. (2008). Unaccepted but tolerated behavior. Educational Considerations, 35(2), 50-51.

Johnson, D. W. (2009). Reaching out: Interpersonal effectiveness and self-actualization. Upper Saddle River, New Jersey: Pearson.

Krahe, B. (2001). The social psychology of aggression. East Sussex: Psychology Press Ltd.

Krefting, L. (1991). Rigour in qualitative research: the assessment of trustworthy-ness. American Journal of Occupational Therapy, 45(3), 214-222.

Kruger, C. (26 Februarie 2012). As die boelie gaan werk (pp. 4-5). My Tyd Rapport, bladsye.

Myburgh, C. P. H., \& Strauss, J. (2013). B.Ed Honours study guide 85516: Research theories and methods. Johannesburg, South Africa: University of Johannesburg.

Peyton, R. (2003). Eliminate bullying and create a positive working environment. London and New York: Brunner-Routledge. 
Randall, P. (2002). Bullying in adulthood: Assessing the bullies and their victims. New York: Brunner-Routledge.

Rayner, C., Hoel, H., \& Cooper, C. L. (2002). Workplace bullying: What we know, who is to blame, and what can we do? London \& New York: Taylor \& Frances.

Scott-Lennon, F., \& Considine, M. (2008). Bullying and harassment: Values and best practice responses. Dublin: Management Briefs.

Streubert, H. J., \& Carpenter, D. R. (2007). Qualitative research in nursing. Advancing the humanistic imperative. Philadelphia: Lippencott.

Tehrani, N. (2001). Building a culture of respect: Managing bullying at work. London: Taylor \& Frances.

Tehrani, N. (2004). Workplace trauma: Concept, assessment and interventions. East Sussex: Brunner-Routledge.
Van der Merwe, D. S. (2013). Die belewenis van aggressie deur die uroue-onderwyser in die werkplek. Unpublished master's dissertation. Johannesburg: University of Johannesburg.

Van Waltsleven, R. (2007). Strategies to assist community nurses who are psychologically abused in interaction with others in their workplace setting. Unpublished master's dissertation. Johannesburg: University of Johannesburg.

Vega, G., \& Comer, D. R. (2005). Sticks and stones may break your bones, but words can break your spirit: bullying in the workplace. Journal of Business Ethics, 58, 101-109.

Venter, M., Poggenpoel, M., \& Myburgh, C. P. H. (2005). The phenomenon of aggressive behavior of learners in the school situation. Education, 126(2), 312-315.

Wiedmer, T. L. (2011). Workplace bullying: costly and preventable. Delta Kappa Gamma Bulletin, 77(2), 35-41. 